\title{
The effectiveness of the use of filter on the tilapia growth performance, number of Nitrosomonas sp., and water quality in aquaponics systems
}

\section{Efektivitas penggunaan filter terhadap performa pertumbuhan ikan nila, jumlah Nitrosomonas sp., dan kualitas air dalam sistem akuaponik}

\author{
Yuli Andriani*, Zahidah, Yayat Dhahiyat, Ujang Subhan, Irfan Zidni, Rusky Intan \\ Pratama, Nadia Purnamasari Gumay
}

Faculty of Fisheries and Marine Sciences, Padjadjaran University

Jln. Raya Bandung Sumedang KM 21, Jatinangor, West Java, Indonesia 40600

*E-mail : yuli.andriani@unpad.ac.id

(Received 18 October 2016; Accepted 14 November 2017)

\begin{abstract}
This study aims to determine the most effective type of living filter media for the bacteria Nitrosomonas sp. in order to improve water quality in aquaponics systems. The method used in this study was completely randomized design, consisting of five treatments and each was repeated three times. The treatments were: A (without addition of filter media), B (addition of palm fibers, silica sand, and activated carbon), C (addition of palm fibers, silica sand, gravel, and activated carbon), D (addition of palm fibers, silica sand, rocks, and activated carbon), and E (addition of palm fibers, silica sand, bioball, and activated carbon). Parameters measured were: 1) the number of Nitrosomonas bacteria, 2) water quality (ammonia, nitrate, and phosphate); and, 3) productivity of fish and Chinese spinach. Data were analyzed using a descriptive method. The findings show that the highest number of bacteria was found in treatment E, $9.29 \times 10^{5} \mathrm{CFU} / \mathrm{mL}$ on the bioball filter media and $4.43 \times 10^{5} \mathrm{CFU} / \mathrm{mL}$ in rearing tanks. The best water quality was in treatment $\mathrm{B}$, with a concentration of ammonia of $0.17 \mathrm{mg} / \mathrm{L}$, nitrate of $0.33 \mathrm{mg} / \mathrm{L}$, and phosphate of $0.54 \mathrm{mg} / \mathrm{L}$. Plant productivity was the best in treatment B in which the average length and weight reach $48.1 \mathrm{~cm}$ and 11.1 grams of plant/week, respectively. The best fish growth was seen in treatment $\mathrm{C}$ with an absolute growth rate of 4.4 grams and a specific growth rate of 1.9\%/day. The recommended filter was made of Arenga pinnata fibers, silica sand, gravels, and active carbon of about $2 \mathrm{~cm}$ thick each. The results showed that the type of filter on the aquaponic system had an effect on the amount of Nitrosomonas sp. in water, water quality, and the productivity of Chinese spinach.
\end{abstract}

Keywords: aquaponics, filter, water quality, Nitrosomonas sp.

\begin{abstract}
ABSTRAK
Penelitian ini bertujuan untuk menentukan jenis filter yang paling efektif sebagai media hidup bakteri Nitrosomonas sp. sehingga menghasilkan kualitas air yang baik dalam sistem akuaponik. Rancangan percobaan yang digunakan adalah rancangan acak lengkap, yaitu lima perlakuan dengan tiga kali pengulangan. Perlakuan dalam penelitian ini meliputi: A (tanpa penambahan media filter), B (penambahan media filter ijuk, pasir silika, dan karbon aktif), C (penambahan media filter ijuk, pasir silika, kerikil, dan karbon aktif), D (penambahan media filter ijuk, pasir silika, batu, dan karbon aktif), dan E (penambahan media filter ijuk, pasir silika, bioball, dan karbon aktif). Parameter yang diamati adalah: 1) jumlah bakteri, 2) kualitas air (meliputi amonia, nitrat, dan fosfat), serta 3) produktivitas ikan dan kangkung air. Data hasil penelitian dianalisis secara deskriptif. Hasil penelitian menunjukkan bahwa

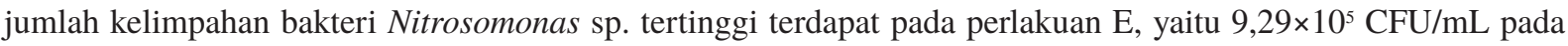
media filter bioball dan $4,43 \times 10^{5} \mathrm{CFU} / \mathrm{mL}$ pada media air pemeliharan. Adapun kualitas air terbaik yaitu pada perlakuan B dengan konsentrasi amonia $0,17 \mathrm{mg} / \mathrm{L}$, nitrat $0,33 \mathrm{mg} / \mathrm{L}$, dan fosfat $0,54 \mathrm{mg} / \mathrm{L}$. Produktivitas kangkung terbaik yaitu pada perlakuan B dengan panjang rata-rata mencapai 48,1 cm dan bobot tanaman 11,1 gram/minggu. Pertumbuhan ikan terbaik terdapat pada perlakuan C, dengan nilai pertumbuhan ikan mutlak sebesar 4,4 gram dan pertumbuhan spesifik 1,9\%/hari. Hasil penelitian menunjukkan bahwa jenis filter pada sistem akuaponik berpengaruh terhadap jumlah Nitrosomonas sp. dalam air, kualitas air, dan produktivitas tanaman kangkung. Filter yang disarankan dari hasil penelitian ini adalah yang tersusun atas ijuk, pasir silika, batukerikil, dan karbon aktif masing-masing setinggi $\pm 2 \mathrm{~cm}$.
\end{abstract}




\section{INTRODUCTION}

Aquaponics is an aquaculture technology that integrates the cultivation of fish and plants (Danaher et al., 2013). In principle, aquaponics is a biointegration between aquaculture activities and hydroponic plants or vegetables that can be applied in a condition where land and water resource are limited, including in urban areas (Hermawan, 2015). In addition, waste produced by the aquaculture, such as unconsumed feed or fish feces can be used to fertilize plants with the help of nitrifying bacteria. Cultivation using aquaponics system is already done in some species of fish such as tilapia. Tilapia has favorable properties, i.e. it is easy to be cultured, grows rapidly, and is easy to grow in intensive culture system (Nugroho et al., 2013).

In general, aquaponics uses recirculating systems. Mulyadi and Yani (2014) stated that water recirculation in aquaculture provides biological balance, stabilizes temperature, assists oxygen distribution, and reduces the accumulation of hazardous materials. Considering a few clean water sources nowadays, it is necessary to maintain water quality in aquaculture, especially in the recirculation system. One of the ways is by using water filters. Traditionally, filters refine freshwater using certain media to produce clean water. According to Samsudari and Wirawan (2013), the filter in the recirculation system serves as a mechanical function to purify water and a biological function to convert ammonia into nitrate. Several commonly used filters in recirculation system are physical, chemical, and biological filters, such as zeolites, gravestone
Taiwan Anodonta woodiana and lettuce Lactuca sativa (Putra et al., 2011). The aim of this study was to discover the best type of filter that is able to produce appropriate water quality that supports fish cultivation productivity in an aquaponics system that integrates tilapia fish and Chinese spinach cultivation.

\section{MATERIALS AND METHODS}

\section{Experimental design}

This study was conducted from March to May 2016 at the Ciparanje Aquaculture Laboratory, Faculty of Fisheries and Marine Science, Padjadjaran University. Water quality was tested at the Marine Resources Management Laboratory, Faculty of Fisheries and Marine Science, Padjadjaran University. Bacteria were tested at the Microbiology Laboratory, Faculty of Mathematics and Natural Science, Padjadjaran University. The experimental design used was a completely randomized design consisting of five treatments, repeated three times. The treatments are: A (without filter (control)), B (filter made of Arenga pinnata fibers, silica sand, and active carbon), C (filter made of Arenga pinnata fibers, silica sand, gravels, and active carbon), D (filter made of Arenga pinnata fibers, silica sand, corals, and active carbon), and E (filter made of Arenga pinnata fibers, silica sand, bioball, and active carbon). Parameters measured were: 1) the number of Nitrosomonas bacteria, 2) water quality (ammonia, nitrate, and phosphate); and, 3) productivity of fish and Chinese spinach. Each filter treatment has two $\mathrm{cm}$ thick. The layout of the filter used in this study is shown in Figure 1.

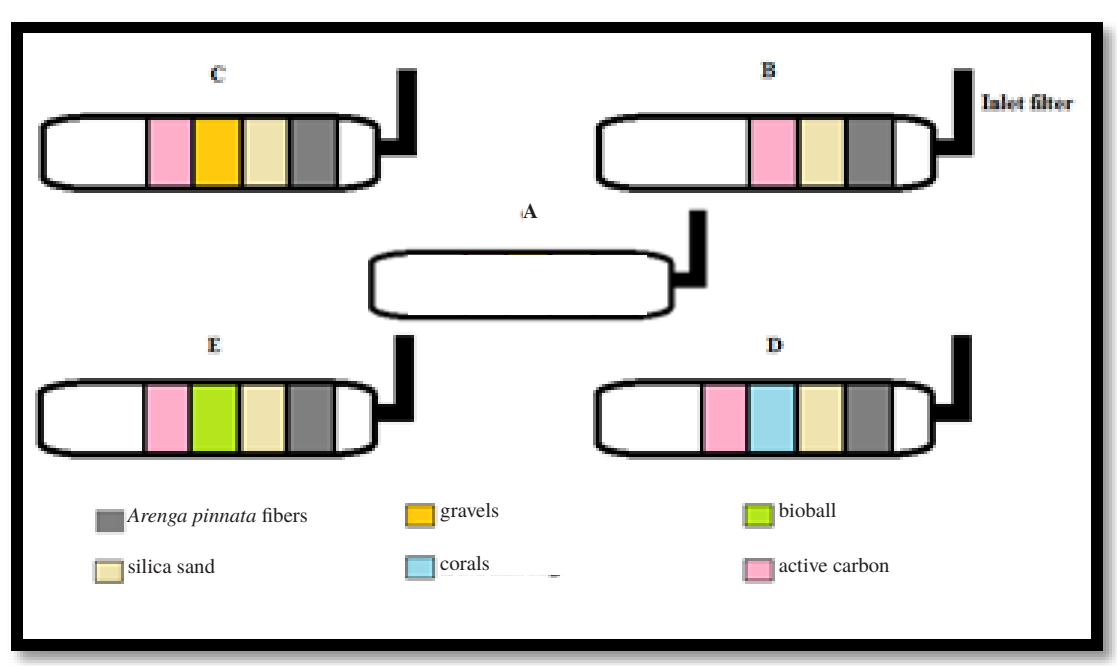

Figure 1. Filter composition layout. Treatment A uses no additional filters. Treatment B uses filters is palm fibers, silica sand, and activated carbon. Treatment $\mathrm{C}$ uses filters is palm fibers, silica sand, gravel, and activated carbon. Treatment D uses filters is palm fibers, silica sand, rocks, and activated carbon. Treatment E uses filters is palm fibers, silica sand, bioball, and activated carbon. 


\section{Preparation}

Preparation of containers and filters

The preparation stage involved cleaning container ponds, draining ponds, the installation of tarps sizing $1 \times 1 \mathrm{~m}$, and filling water. The container used in this study was a concrete pond sizing $2 \times 1 \mathrm{~m}$ which was then covered using $100 \times 60 \mathrm{~cm}$ plywood and tarpaulin with a size of $1 \times 1 \mathrm{~m}$. Plants were cultivated in containers equipped with a styrofoam. The styrofoam was perforated with a $10 \mathrm{~cm}$ interval between holes to prevent the plants from sinking.

The filter used contained physical filtering media (Arenga pinnata, fibers, and silica sand), chemical filtering media (active carbon), and biological filtering media (gravels, corals, and bioball). Each filter material was inserted into a PVC pipe (diameter 2 inches, height $30 \mathrm{~cm}$ ) with a thickness of about $2 \mathrm{~cm}$ each. The order of the materials was physical, biological, chemical, and another physical (only Arenga pinnata fiber) filtering media, respectively. The aquaponics system design used is depicted in Figure 2.

\section{Acclimatization of fish}

Acclimatization of fish was done so that the fish could adapt to the new environment would not be stressed when this study was conducted. Acclimatization was done for $4-8$ days. After the fish had been able to adapt to the new environment, the fish were transferred into the rearing pond.

\section{Planting Chinese spinach}

The cultivation of the Chinese spinach was performed by moving two-week-old Chinese spinach from the initial cultivation media (soil) into the new planting media (rockwool).

\section{Aquaponics system design}

In this study, fifteen $1 \mathrm{x} 1 \mathrm{~m}$ tarp pools were used. The pools were filled with water until it reached $30 \mathrm{~cm}$. The stocking density of each pond was $100 \mathrm{fish} / \mathrm{m}^{2}$. The filter was installed by tying it on a bamboo under the water gutter using wires. Before starting the aquaponics system, the initial length and weight of the fish and the length of the Chinese Spinach were measured. The plants were then moved to the cultivation media with an interval of $10 \mathrm{~cm}$ between plants.

\section{Implementation}

This study was conducted over 42 days. The condition of the fish, plants, and also filters were monitored every day. The fish were fed at a feeding rate of $5 \%$ of body weight three times a day (morning at 09:00 am, daytime at 01:00 pm, and the afternoon at $05.00 \mathrm{pm}$ ). Fish weighed and measured every two weeks. The water quality was monitored every week. Harvesting plants and counting the number of bacteria were carried out at the end of the study.

\section{Parameters}

Water quality parameters

Water quality parameters observed were temperature, acidity $(\mathrm{pH})$, dissolved oxygen (DO), ammonia, phosphate, and nitrate (Nugroho \& Tanjung, 2014; Boyd \& Linchtkoppler, 1982).

\section{The number of Nitrosomonas sp. bacteria}

The nitrifying bacteria counted in this study was Nitrosomonas sp. The bacteria inoculated were collected from the pond water and from the biological filtering media used. In the middle of the study, inoculation was only done for bacteria from the pond water while at the end of the study, the inoculation was performed for bacteria from water and biological filtering media, i.e. gravels, corals, and bioball. The selective media used is a specific medium for Nitrosomonas (Elbanna et al., 2012). The observation was conducted for 2 weeks for each nitrifying bacterial inoculation.

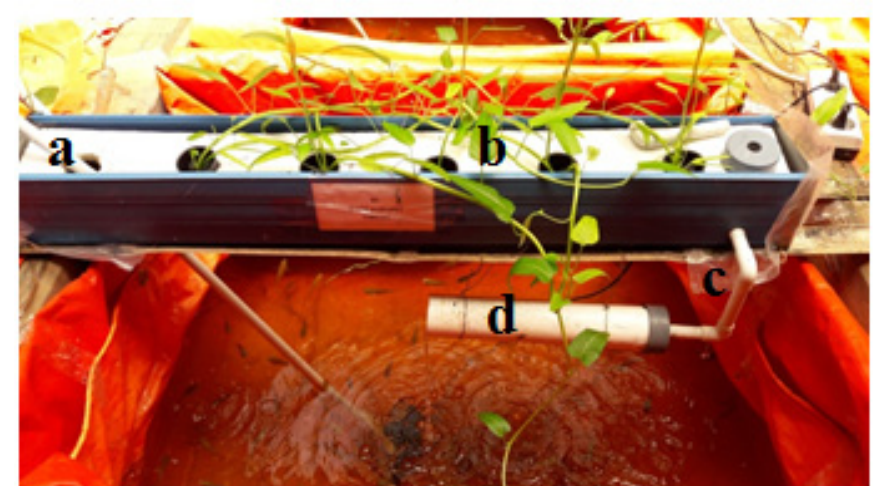

Figure 2. Aquaponics system design. (a) inlet channel, (b) Chinese spinach, (c) outlet channel, (d) filter. 
The counting of the bacteria was done by total plate count (TPC) (Salosa, 2013) using the following formula:

Bacterial samples were derived from the pond water and the used biological filter media. While the research conducted at the end of the inoculation of bacteria from water and filter media. Selective medium is used for Nitrosomonas sp (Elbanna et al., 2012). These observations were made during 2 weeks for one inoculating bacteria nitrification bacteria count was calculated using total plate count (TPC) (Salosa, 2013) with the formula:

The number of bacteria $(\mathrm{CFU} / \mathrm{mL})$

$=$ the number of colony $\times 1 /$ dilution factor

\section{Fish and plant growth}

Observations of the fish growth (sampling) were done by taking the fish at a number of $30 \%$ of the total population in each pond. After sampling, an adjustment in the amount of feed was made for the following week.

Weight gain and growth rate of the fish was calculated using the following formulas (Andriani et al., 2017):

a. Absolute growth

$$
\begin{aligned}
& \quad \mathrm{PM}=\mathrm{W}_{2}-\mathrm{W}_{1} \\
& \text { Note: } \\
& \mathrm{PM}=\text { Absolute growth }(\mathrm{g}) \\
& \mathrm{W}_{1}=\text { Initial weight of fish }(\mathrm{g}) \\
& \mathrm{W}_{2}=\text { Final weight of fish }(\mathrm{g})
\end{aligned}
$$

b. Specific growth rate

$$
\begin{aligned}
& \mathrm{SGR}=\left(\ln \mathrm{W}_{2}-\ln \mathrm{W}_{1}\right) / \mathrm{T} \times 100 \\
& \text { Note: } \text { Specific growth rate }(\% / \text { day }) \\
& \mathrm{SGR}= \text { Sperish }(\mathrm{g}) \\
& \mathrm{W}_{1} \quad=\text { Initial weight of fish } \\
& \mathrm{W}_{2} \quad=\text { Final weight of fish }(\mathrm{g}) \\
& \mathrm{T}= \text { The number of days during rearing } \\
& \text { period (days) }
\end{aligned}
$$

Observation of plant growth was conducted at the beginning and the end of the study. At the beginning of the study, experimental plants were weighed using a digital scale, then measured their length with a ruler before they were transferred into the new planting medium. In the middle of the study conducted in the same manner with the beginning but do crop plants by cutting the stem of the plant and be left high as about $5 \mathrm{~cm}$. Harvesting the middle of this research is done to prevent the occurrence of plant death because at that time the plant has reached the size ready for consumption. At the end of the study conducted the same as in the beginning and in the middle of research. Plant weight gain was calculated by the same calculation method with the weight of fish, while the growth rate of plants is calculated by measuring the length of the plant.

The observation on the plant's growth was performed at the start, middle and at the end of the study. In the start of the study, the observation was performed by weighing the plants using a digital scale and measuring the length of the plant using a ruler before they are moved to a new planting media. In the middle of the study, the same measurements were performed but they were performed on the harvested plants. The plants were harvested by cutting the stem and left about $5 \mathrm{~cm}$ stem from the remaining plants. The harvesting in the middle of the study was performed to prevent plant death because at that time the plants had reached the height of ready-toconsume Chinese spinach. At the end of the study, the measurements were performed using the same method used at the start and in the middle of the study.

\section{Data analysis}

The effects of treatment on fish and plant growth were analyzed descriptively, meanwhile, water quality analyzed descriptively compared to the standards set out in the Government Regulation No. 82 of 2001 and water standards for Nile tilapia culture issued by Sukabumi Freshwater Aquaculture Development Center in 2016.

\section{RESULTS AND DISCUSSION}

\section{Water quality parameters}

The water quality is one of the parameters that can use to indicate the filter efficiency. The water quality during the study was shown in Table 1 . The concentration of ammonia in this study is between 0.11 and $0.20 \mathrm{mg} / \mathrm{L}$, while the acidity was between 7.47 and 7.52. According to the water standards (Sunarma, 2016), the concentration of dissolved ammonia in the rearing tanks is within acceptable limits for Nile tilapia culture; the threshold is $<0.2 \mathrm{mg} / \mathrm{L}$, while the optimum acidity for Nile tilapia culture is between 6.5 and 8.5. Ammonia in water is proportional to its acidity. Acidity tends to increase the concentration of ammonia, which is harmful to fish whereas basicity tends to increase the probability of ammonium hydroxide $\left(\mathrm{NH}_{4} \mathrm{OH}\right)$ forming. The low concentration of 
Table1. Water quality of the study

\begin{tabular}{ccccccc}
\hline \multirow{2}{*}{ Treatment } & \multicolumn{5}{c}{ Water quality } \\
\cline { 2 - 6 } & Ammonia & Nitrate & Phosphate & DO & pH & Temperature \\
\hline A & 0.11 & 0.76 & 1.23 & 4.3 & 7.5 & 25.6 \\
B & 0.17 & 0.33 & 0.54 & 5.4 & 7.5 & 26.2 \\
C & 0.18 & 0.58 & 0.44 & 6.1 & 7.5 & 26.1 \\
D & 0.20 & 0.60 & 0.67 & 4.2 & 7.5 & 26.1 \\
E & 0.17 & 0.49 & 0.73 & 4.7 & 7.5 & 26.1 \\
Standard & $<0.2 \mathrm{mg} / \mathrm{L}$ & $10-20 \mathrm{mg} / \mathrm{L}$ & $<1 \mathrm{mg} / \mathrm{L}$ & $>5 \mathrm{mg} / \mathrm{L}$ & $6.5-8.5$ & $25-30{ }^{\circ} \mathrm{C}$ \\
\hline
\end{tabular}

Note: Treatment A uses no additional filters. Treatment B uses filters is palm fibers, silica sand, and activated carbon. Treatment $\mathrm{C}$ uses filters is palm fibers, silica sand, gravel, and activated carbon. Treatment $\mathrm{D}$ uses filters is palm fibers, silica sand, rocks, and activated carbon. Treatment E uses filters is palm fibers, silica sand, bioball, and activated carbon.

ammonia is linked to the biological filter media used. Compared to physical and chemical filter media, biological media plays a more significant role in improving water quality as it harbors the necessary bacteria to decompose harmful materials dissolved in water, among which is ammonia. The value of ammonia in this study was lower than that of Mulqan et al. (2017) in Nile tilapia fish in aquaponic system with Chinese spinach that is $0.648-0.974 \mathrm{mg} / \mathrm{L}$.

The concentration of nitrate in this study is between 0.33 and $0.76 \mathrm{mg} / \mathrm{L}$. Government Regulation No. 82 of 2001 sets out the safe concentration of nitrate in Class II and Class III water as $10 \mathrm{mg} / \mathrm{L}$ and $20 \mathrm{mg} / \mathrm{L}$, respectively. The concentration of nitrate in this study is lower when compared to the research conducted Nuwansi et al. (2017), whose concentration is between 1.66 and $3.36 \mathrm{mg} / \mathrm{L}$.

Phosphate found in the rearing tanks are from residual feed and fish feces. The concentration of phosphate in this study is between 0.44 and $1.23 \mathrm{mg} / \mathrm{L}$. Concentrated levels of phosphate in water are caused by the accumulation of residual feed and metabolic wastes, in turn decreasing dissolved oxygen levels (Lestari et al., 2015). The concentration of phosphate in water is proportional to the population of phytoplankton in it. Government Regulation No. 82 of 2001 defines the safe concentration of phosphate in Class II and Class III water as $0.2 \mathrm{mg} / \mathrm{L}$ and 1 $\mathrm{mg} / \mathrm{L}$, respectively. This is in line with the results of research Hasan et al. (2017) which states that the treatment with aquatic plants in aquaponic reduce the phosphate concentration, due to phosphate being used by the plant as a nutrient.

The level of dissolved oxygen in this study is between 4.2 and $6.1 \mathrm{mg} / \mathrm{L}$. The level of dissolved oxygen in some of the treatments are below acceptable amounts as the volume of the filter container is not balanced with the volume of water handled by the system. Higher levels of dissolved oxygen are is beneficial to the growth of Nile tilapia spawns. Fish requires dissolved oxygen to sustain its respiratory and metabolism functions. Low levels of dissolved oxygen hinder fish's respiratory functions which in turn negatively affects its metabolism. Oxygen is a limiting factor, wherein insufficient oxygen affects all and every of the fish's activities and growth. Moreover, an acute lack of oxygen causes death (Yurisma et al., 2013). According to the Water Standards (Sunarma, 2016), the optimum level of dissolved oxygen for culturing Nile tilapia is $>5 \mathrm{mg} / \mathrm{L}$.

In this study, the water temperature between 25.6 and $26.2{ }^{\circ} \mathrm{C}$. The temperature range is within the acceptable limits set out in the Water Standards (Sunarma, 2016). The optimum water temperature for Nile tilapia culture is $25-30{ }^{\circ} \mathrm{C}$. Water temperature directly affects, among others, fish growth, dietary needs, and feed conversion efficiency (Zou et al., 2016).

\section{The number of Nitrosomonas sp.}

Nitrifying bacteria in the nitrogen cycle is crucial, as it affects water quality. The number of nitrifying bacteria present in water determines the concentrations of ammonia, nitrite, and nitrate. The number of bacteria is shown in Table 2 .

Treatment $\mathrm{E}$ contains the highest number of bacteria: $9.29 \times 10^{5} \mathrm{CFU} / \mathrm{mL}$ on the biological filter and $4.43 \times 10^{5} \mathrm{CFU} / \mathrm{mL}$ in the rearing tank. The difference in the number of bacteria in each treatment caused by differences in the available surface area. Treatment $\mathrm{E}$ uses bioball whereas treatment $\mathrm{C}$ uses gravel and treatment $\mathrm{D}$ uses rocks. Bioball offers greater surface area compared to gravel and rocks. Factors which affect bacteria 
Table 2. Number of Nitrosomonas sp. in individual treatments

\begin{tabular}{ccc}
\hline \multirow{2}{*}{ Treatment } & \multicolumn{2}{c}{ Number of bacteria $(\mathrm{CFU} / \mathrm{mL})$} \\
\cline { 2 - 3 } & In water & On filter \\
\hline A & $3.78 \times 10^{4}$ & - \\
B & $3.17 \times 10^{4}$ & - \\
C & $1.45 \times 10^{4}$ & $8.01 \times 10^{5}$ \\
D & $7.12 \times 10^{3}$ & $4.20 \times 10^{5}$ \\
E & $4.43 \times 10^{5}$ & $9.29 \times 10^{5}$ \\
\hline
\end{tabular}

Note: Treatment A uses no additional filters. Treatment $\mathrm{B}$ uses filters is palm fibers, silica sand, and activated carbon. Treatment C uses filters is palm fibers, silica sand, gravel, and activated carbon. Treatment D uses filters is palm fibers, silica sand, rocks, and activated carbon. Treatment E uses filters is palm fibers, silica sand, bioball, and activated carbon.

growth on filters are, among others, filter surface area, water temperature, water $\mathrm{pH}$, dissolved oxygen levels, and sunlight intensity (FAO, 2014). The size of the surface area of a filter media is proportional to the number of bacteria it harbors.

The number of bacteria in treatment $\mathrm{E}$ was in line with low ammonia concentrations at the end of the study. The number of bacteria present determines the concentrations of ammonia and nitrate in water. Weekly readings of ammonia concentration in treatment $\mathrm{E}$ show a steady decline compared with other treatments, due to the use of bioball as the biological filter in the treatment. Bioballs made of PVC which have a specific surface area and large cavities, harboring greater numbers of bacteria and minimizes the risk of obstruction (Alfia et al., 2013).

Analysis on the number of bacteria was aimed to determine the most effective biological filter to support the growth of nitrifying bacteria. The inoculated bacteria was Nitrosomonas sp., a nitrifying bacteria which oxidizes ammonia into nitrite. Based on observation, Nitrosomonas sp. are circular and white in color. Identification of bacteria using a specific medium for Nitrosomonas, so it can be ascertained bacteria identified was Nitrosomonas.

The biological role of bacteriagrowth in the filter media is to oxidize nitrogen from metabolism and fish feces into fertilizer. Nitrogen in water typically takes the form of nitrogen gas $\left(\mathrm{N}_{2}\right)$, ammonia $\left(\mathrm{NH}_{3}\right)$, ammonium $\left(\mathrm{NH}_{4}{ }^{+}\right)$, nitrite $\left(\mathrm{NO}_{2}\right)^{-}$, nitrate $\left(\mathrm{NO}_{3}^{-}\right)$, and organic nitrogen. Organic nitrogen is a coordination complex of a number of materials such as amino acids, amino sugars, and protein (polymer) which are ready to be oxidized into ammonium by bacteria in water (Zou et al., 2016).

The process of nitrification consists of two stages. The first stage is nitritation, wherein ammonia $\left(\mathrm{NH}_{3}\right)$ is oxidized into nitrite $\left(\mathrm{NO}_{2}{ }^{-}\right)$ by ammonia-oxidizing bacteria (AOB), namely Nitrosomonas sp. The second stage is nitration, wherein nitrite $\left(\mathrm{NO}_{2}{ }^{-}\right)$is oxidized into nitrate $\left(\mathrm{NO}_{3}{ }^{-}\right)$by nitrite-oxidizing bacteria (NOB), namely Nitrobacter sp. (FAO, 2014). The reaction is as follows:

$$
\begin{aligned}
& \mathrm{NH}_{4}^{+}+1.5 \mathrm{O}_{2} \rightarrow \mathrm{NO}_{2}^{-}+2 \mathrm{H}^{+}+2 \mathrm{H}_{2} \mathrm{O}+84 \mathrm{kcal} / \mathrm{mole} \text { ammonia } \\
& \mathrm{NO}_{2}^{-}+0.5 \mathrm{O}_{2} \rightarrow \mathrm{NO}_{3}^{-}+17 \mathrm{kcal} / \text { mole nitrite } \\
& \mathrm{NH}_{4}^{+}+2 \mathrm{O}_{2} \rightarrow \mathrm{NO}_{3}^{-}+2 \mathrm{H}_{2}^{+}+\mathrm{H}_{2} \mathrm{O}+\text { energy }
\end{aligned}
$$

Nitrifying bacteria optimally growth in temperatures from $17-34{ }^{\circ} \mathrm{C}, \mathrm{pH} \quad 6-8.5$, and dissolved oxygen $4-8 \mathrm{mg} / \mathrm{L}$ (FAO, 2014). The number of bacteria on the biological filter media is higher compared to that of Nurhidayat and Ginanjar (2010), i.e. $5.5 \times 10^{3} \mathrm{CFU} / \mathrm{mg}$ on the bioball and $2.64 \times 10^{3} \mathrm{CFU} / \mathrm{mg}$ on the zeolite $(1$ $\mathrm{mL}$ is equivalent to $10 \mathrm{mg}$, thus $9.29 \times 10^{5} \mathrm{CFU} /$ $\mathrm{mL}$ is equivalent to $9.29 \times 10^{4} \mathrm{CFU} / \mathrm{mL}$ ).

\section{Fish and plant growth}

\section{Fish growth}

Fish growth observed during the study that the rate of growth and absolute growth (Table 3). Specific growth rate was lower when compared to the research conducted Alfia et al. (2013) ranged from 2.6 to $3.3 \%$. The difference in the percentage of the specific growth rate is presumably because stocking density used is different so it affects the fish's ability to digest food. High stocking density which can cause space to be limited so as hamper fish for food (Alfia et al., 2013). Fish growth in aquaponic is affected by the existences of probiotic microbes in the water. It was proven by the increasing specific growth of catfish-water spinach in the aquaponic system, namely $2.386 \%$, with using probiotic (Primashita et al., 2017). Another factor that affects fish growth is water quality. Yildiz et al. (2017) state the water quality, which directly affects fish health and well-being, is the key factor to be considered in all aquaponic systems.

The magnitude of the growth rate is directly proportional to the magnitude of absolute growth. The growth of tilapia fish on the best available treatment A with a growth rate of $2.1 \%$ per day and absolute growth of 5.8 grams. This shows that the use of filter is unable to increase the fish growth in an aquaponics system. 
Table 3. The effect of treatment on the growth of fish

\begin{tabular}{ccc}
\hline \multirow{2}{*}{ Treatment } & \multicolumn{2}{c}{ Growth } \\
\cline { 2 - 3 } & Absolute (gram) & Specific (\%/day) \\
\hline A & $5.8 \pm 0.76$ & $2.1 \pm 0.10$ \\
B & $3.9 \pm 0.42$ & $1.8 \pm 0.10$ \\
C & $4.4 \pm 0.96$ & $1.9 \pm 0.15$ \\
D & $3.4 \pm 0.87$ & $1.7 \pm 0.11$ \\
E & $3.4 \pm 0.06$ & $1.7 \pm 0.05$ \\
\hline
\end{tabular}

Note: Treatment A uses no additional filters. Treatment $B$ uses filters is palm fibers, silica sand, and activated carbon. Treatment $\mathrm{C}$ uses filters is palm fibers, silica sand, gravel, and activated carbon. Treatment D uses filters is palm fibers, silica sand, rocks, and activated carbon. Treatment E uses filters is palm fibers, silica sand, bioball, and activated carbon.

\section{Plant growth}

Based on the results of studies measuring the height of the plant obtained an average at $63.2 \mathrm{~cm}$ (Table 4). This is presumably due to differences in density are used. High plant density can lead to competitive absorption of nutrients by plants so that the plants cannot grow optimally.

The result showed that in the aquaponics system, water plant has a different response in growth. Andriani et al. (2017) showed that the length of water-spinach reached $20-25 \mathrm{~cm}$, while on lettuce the harvesting size was reached at the fourth week with average length 27.28 $\mathrm{cm}$. The Chinese spinach weights increase in an aquaponic biofilter system is influenced by the degree of utilization of nutrient derived from the degradation of residual feed and fish metabolism waste product by nitrifying bacteria (Muhammad et al., 2016).

The increase in plant's length and weight does not have positive correlation due to the influence of otherfactors on growth, such as nutrients in the form of phosphate and nitrate and light intensity. This is apparent in treatment $\mathrm{C}$ where the light intensity was higher than the nutrients absorbed, leading to a condition where the plants in this treatment had the tallest height but not the biggest weight.

\section{CONCLUSIONS}

Based on its findings, this study concludes that the use of silica sand, gravels, and active carbon (treatment C) as filter media is the most effective in improving water quality so as to support aquaculture and hydroponics. The use of such filter media resulted in a concentration of ammonia of $0.18 \mathrm{mg} / \mathrm{L}$, phosphate of 0.44 $\mathrm{mg} / \mathrm{L}$, and nitrate of $0.58 \mathrm{mg} / \mathrm{L}$. The number of Nitrosomonas bacteria were $1.45 \times 10^{4} \mathrm{CFU} / \mathrm{mL}$ on the filter media and $8.01 \times 10^{5} \mathrm{CFU} / \mathrm{mL}$ in the water. The productivity of plants is high, reaching a length and weight of $63.2 \mathrm{~cm}$ and 7.5 grams, respectively, while the absolute growth rate of 4.4 grams and a specific growth rate of $1.9 \% /$ day.

\section{REFERENCES}

Alfia AR, Arini E, Elfitasari T. 2013. The effect of density differences on survival and growth of Nile tilapia Oreochromis niloticus in recirculation system with bioball filter. Journal of Aquaculture Management and Technology $2: 86-93$.

Andriani Y, Yayat D, Zahidah, Zidni I. 2017. The effect of stocking density ratio of fish on water plant productivity in aquaponics culture system. Nusantara Bioscience 9: 31-35.

Boyd CE, Linchtkoppler F. 1982. Water quality development series No. 22. Auburn, Alabama: International Center for Aquaculture. Aquaculture Experiment Station.

Danaher JJ, R. Charlie S, James E. Rakocy and

Table 4. Effect of treatment on plant growth

\begin{tabular}{ccccccccc}
\hline \multirow{2}{*}{ Treatment } & \multicolumn{4}{c}{ Height $(\mathrm{cm})$} & \multicolumn{5}{c}{ Weight (gram/week) } \\
\cline { 2 - 9 } & Initial & Middle & Final & Average & Initial & Middle & Final & Average \\
\hline A & 8.1 & 75.2 & 20 & 34.43 & 0.9 & 15.4 & 3.3 & 6.5 \\
B & 9.4 & 96.8 & 76.7 & 61.1 & 1.0 & 18.1 & 24.4 & 14.5 \\
C & 10.8 & 85.9 & 92.8 & 63.2 & 1.1 & 8.3 & 13.2 & 7.5 \\
D & 11.6 & 90.5 & 47.7 & 50 & 1.3 & 10.2 & 6.7 & 6.1 \\
E & 11.9 & 104.2 & 48.2 & 55.1 & 1.1 & 5.7 & 24.1 & 13.6 \\
\hline
\end{tabular}

Note: Treatment A uses no additional filters. Treatment B uses filters is palm fibers, silica sand, and activated carbon. Treatment $\mathrm{C}$ uses filters is palm fibers, silica sand, gravel, and activated carbon. Treatment D uses filters is palm fibers, silica sand, rocks, and activated carbon. Treatment E uses filters is palm fibers, silica sand, bioball, and activated carbon. 
Donald S. Bailey.2013. Alternative solids removal for warm water recirculating raft aquaponic systems. Journal of the World Aquaculture Society 44: 374-383.

Elbanna Kh, El-Shahawy RM, Atalla KM. 2012. A new simple method for the enumeration of nitrifying bacteria in different environment. Plant, Soil and Environment 58: 49-53.

[FAO] Food and Agriculture Organization. 2014. Small-scale aquaponic food production integrated fish and plant farming. Roma: Fisheries and Aquacultural Technical Paper.

Hasan ZY, Dhahiyat, Andriani Y, Zidni I. 2017. Water quality improvement of Nile tilapia and catfish polyculture in aquaponics system. Nusantara Bioscience 9: 83-85.

Hermawan D. 2015. Aquaponic technological applicaton on low salinity vaname shrimp Litopenaeus vannamei rearing with lettuce plant on different spreading density. Journal of Agriculture and Fisheries Science 4: 79-85.

Internal Department Committee Republic of Indonesia. 2001. Government Regulaton Republic of Indonesia concerning Water Quality Management and Controlling Water Contamination Number 82 Year 2001. Jakarta: State Secretariat.

Lestari NAA, Diantari R, Efendi E. 2015. Decrease of phosphate on recirculation system with different filter addition. Journal of Waters Engineering and Aquaculture Technology 3: 367-374.

Muhammad FM, Sri H, Sarjito. 2016. The effect of biofilter aquaponics systems on blood of profile, histology of heart and survival rate of African catfish Clarias gariepenus. Journal of Aquaculture Management and Technology 5: 64-72.

Muhammad M, Sayyid AER, Irma D. 2016. The growth and survival rates of tilapia juvenile Oreochromis niloticus in aquaponics systems with different plants species. Jurnal Ilmiah Mahasiswa Kelautan dan Perikanan Unsyiah 2: 183-193.

Mulyadi UT, Yani ES. 2014. Recirculation system using different filter on Nile tilapia Oreochromis niloticus growth. Journal of Indonesian Aquacultur and Swamp 2: 117-121.

Nugroho A, Arini E, Elfitasari T. 2013. The effect of density difference on survival and growth of Nile tilapia Oreochromis niloticus in recirculation system with charcoal filter.
Journal of Aquaculture Management and Technology 2: 94-100.

Nugroho AS, Tanjung SD. 2014. Distribusi Serta Kandungan Nitrat dan Fosfat di Perairan Danau Rawa Pening. Bioma 3: 27-41.

Nurhidayat, Ginanjar R. 2010. Biofilter function in recirculaton system for albino Pangasius hypophthalmus fingerling rearing [Proceeding]. Bangkok: Aquaculture Technology Innovation Forum.

Nuwansi KKT, Verma1 AK, Tiwari VK, Chandra P, Chandrakant MH. 2017. Standardization of the stocking density ratios of koi carp Cyprinus carpio var. koi: goldfish Carassius auratus in Polyculture Aquaponic Recirculating System. Turkish Journal of Fisheries and Aquatic Sciences 17: 1271-1278.

Primashita AH, Boedi Setya R, Prayogo. 2017. Effect addition of different probiotic in aquaponic systems towards the growth rate and survival rate of catfish Clarias sp.). Journal of Aquaculture Science 1: 1- 9.

Putra I, Setiyanto DD, Wahyuningrum D. 2011. Growth and survival nile tilapia Oreochromis niloticus on recirculation system. Journal of Fisheries and Marines 16: 56-63.

Salosa YY. 2013. Examination of formalin and salt concentrations and total bacteria in the mackerel salted fish from Sarmi District, Papua Province. Depik Journal 2: 10-15.

Samsudari S, Wirawan GA. 2013. Biofilter application analysis in recirculation system on water quality of Anguilla bicolor culture. GAMMA Journal 8: 86-97.

Sunarma A. 2016. Water quality standard for aquaculture. Sukabumi Freshwater Aquaculture Development Agency. http:// www.bbpbat.net/index.php/artikel/60-bakumutu-kualitas-air-budidaya. [31 Mei 2016].

Yildiz HY, Lidia R, Juhani P, Elena M, David, Giuliana P. 2017. Fish welfare in aquaponic systems: its relation to water quality with an emphasis on feed and faeces. Water 9: 1-7.

Yurisma EH, Abdulgani N, Mahasri G. 2013. The effect of different salinity on oxygen conxumption rate Osphronemus gouramy in laboratory scale. Jurnal Sains dan Seni 1: 1-4.

Zou Y, Zhen H, Jian Z, Huijun X, Christophe G, Yinke F. 2016. Effect of pH on nitrogen transformation in media-based aquaponics. Bioresource Technology 210: 81-87. 